\title{
A NEW SETTING PROTOCOL FOR DISTANCE RELAY PROTECTION SYSTEMS IN TRANSPOSED TRANSMISSION LINES WITH UNSYMMETRICAL IMPEDANCES
}

\author{
Abou-Hashema M. El-Sayed \\ Minia University, Egypt \\ abouhashema@gmail.com
}

(Received July 6, 2009 Accepted September 13, 2009).

This paper aims to overcome the effect of transposed transmission lines with unsymmetrical impedances on protection systems. Transposition of phases can successfully overcome the problem of unsymmetrical impedances at the end of the line, but fails at the other parts of the line. The effect of this problem appears in the distance measured by the distance relay unit; the measured distance is usually not equal to the actual distance to the fault location. Moreover, this measured distance (measured impedance) has different values at the same fault location according to the fault loop for both the same and different fault types.

Experiments have been carried out to study the effect of the unsymmetrical impedances on the operation of the system protecting against each fault type. The fault types under study are single line-toground, line-to-line and three-phase faults. The fault clearing time, the distance measured by the distance relay unit and the error in this measured distance were determined.

A new setting rule is suggested in order to prevent failure of the distance relay caused by unsymmetrical impedances.

KEYWORDS: Distance relay, Protection system, Transmission line, Setting rules.

\section{INTRODUCTION}

The protection arrangements for any power system must meet basic requirements in terms of reliability, speed, selectivity and cost.

Distance protection is commonly the first component in a typical two-main protection scheme for transmission lines $[1,2]$. The principle of distance relaying is well known and is based on comparing the measured fault loop impedance with a characteristic of a distance relay on the impedance plane $[3,4]$.

Due to the effect of several unmonitored parameters that are uncertain in physical nature, the estimate of the impedance contains some error, which can lead to incorrect protection operation. The operation zones of relays help to prevent financial losses and/or technical jeopardy that might occur due to their incorrect operation [5].

\section{TRANSMISSION LINE MODEL}

Measurements were made on a transmission line model. This model represents a double line of circuits with a length of $150 \mathrm{~km}$. The original voltage and current for this transmission line are $220 \mathrm{kV}$ and $200 \mathrm{~A}$, respectively, modeled by a voltage and 
current of $440 \mathrm{~V}$ and $10 \mathrm{~A}$. To carry out the measurements, the model was connected to the net at Busbar A and to the load at Busbar B, as shown in Fig. 1. The phases of the transmission line model are transposed at 50 and $100 \mathrm{~km}$. The model includes complete protection systems using four digital distance relay units (R1, R2, R3 and R4 in Fig. 1).

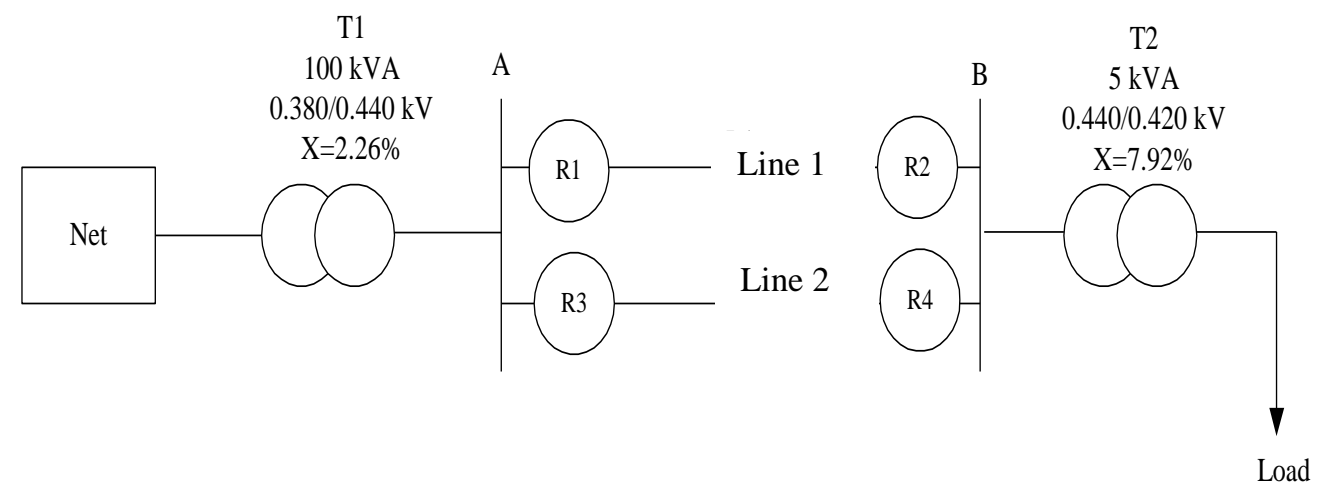

Fig. 1. Transmission line model used in experiments.

\section{SELECTION OF A SUITABLE SETTING RULE}

Different types of setting rules (refs. [6-10]) for the distance relay were tested in order to select the most suitable. To test these rules, numerical calculation was done for one part from the El-Minia substation (an Egyptian city). From this test, the setting rule from ref. [9] was found to be the most suitable to calculate the setting values for the different protection zones of the distance relay units. This rule is most appropriate for many reasons, the most important being the lack of overlap between two or more relays in the same protection zone. This guarantees that the selectivity of the distance relay unit is very high and that the smallest part is isolated from the power system under any fault that occurs $[11,12]$.

\section{EXPERIMENTAL WORK}

To verify the protection system, different types of shunt fault were made for different fault loops, every $5 \mathrm{~km}$ along each line of the model without any fault impedance. The distance to each fault (representing the measured impedance) was measured by the relay. These measurements were carried out with one line in service and also with two lines in service. The experiment was repeated many times using the different setting rules under study [6-10].

Figures 2, 3, 4, 5, 6, 7 and 8 show the actual distance, the distance measured by the distance relays and the \% error of the measured distance for the different fault types and different fault loops, with only line 1 in service. 


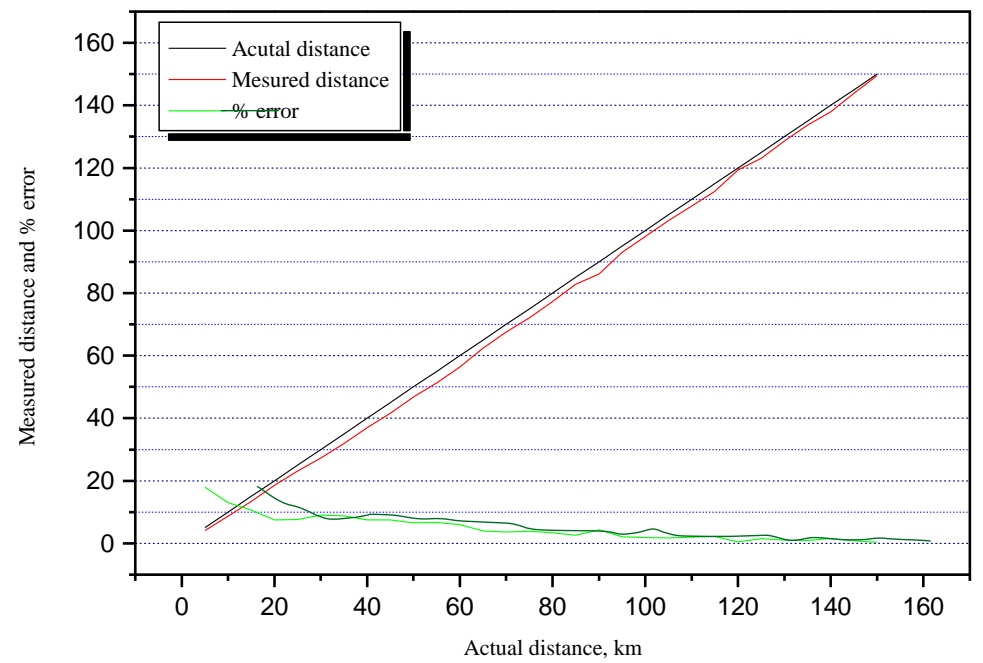

Fig. 2. The distance measured by the distance relays and the $\%$ error in this distance for L1-G fault, line 1 in service.

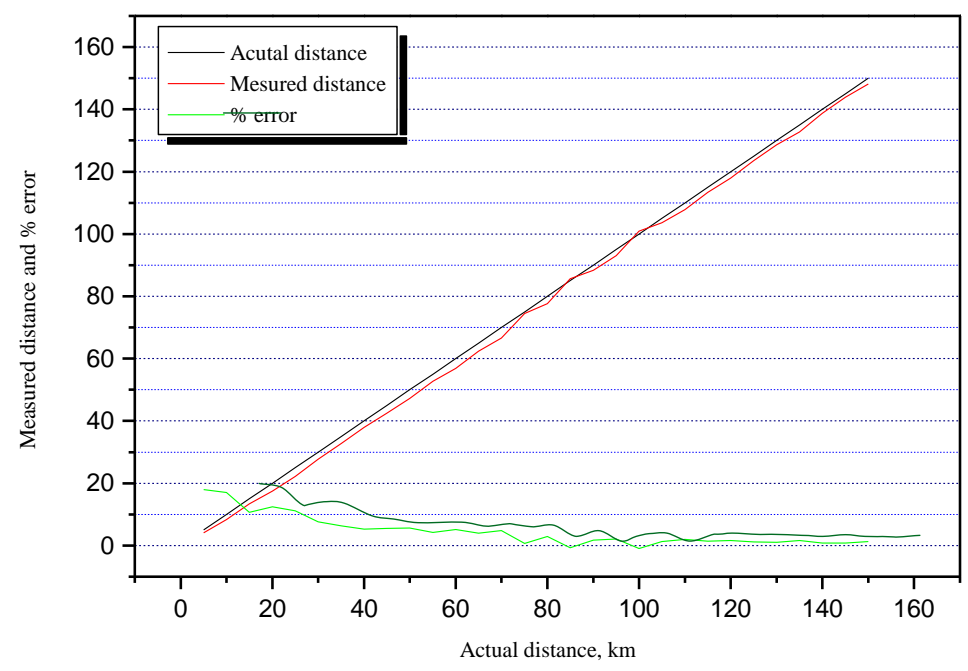

Fig. 3. The distance measured by the distance relays and the $\%$ error in this distance for L2-G fault, line 1 in service. 


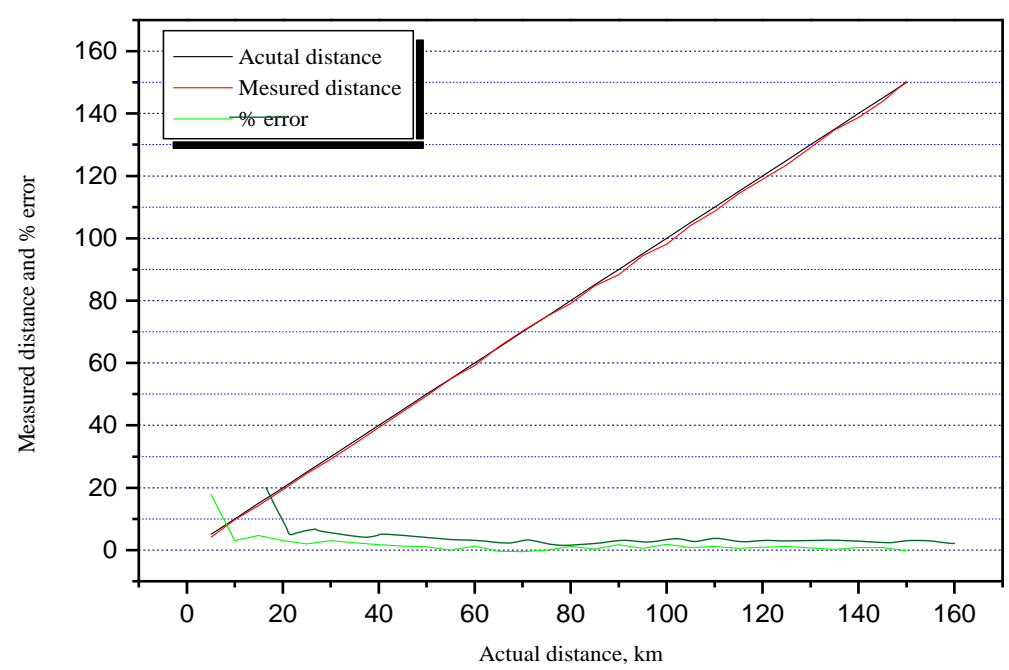

Fig. 4. The distance measured by the distance relays and the $\%$ error in this distance for L3-G fault, line 1 in service.

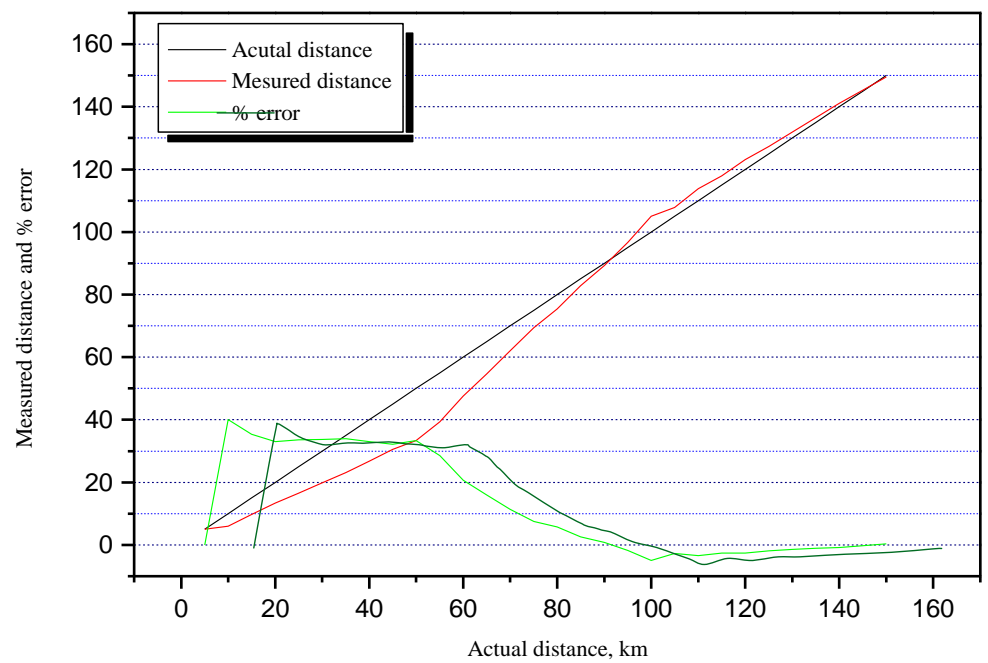

Fig. 5. The distance measured by the distance relays and the $\%$ error in this distance for L1-L2 fault, line 1 in service. 


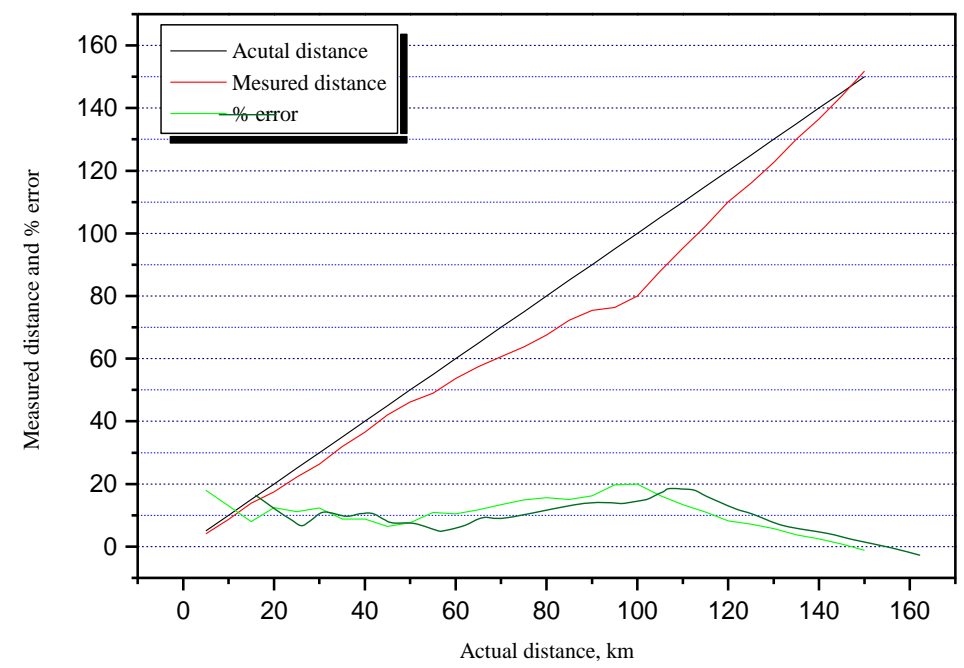

Fig. 6. The distance measured by the distance relays and the $\%$ error in this distance for L1-L3 fault, line 1 in service.

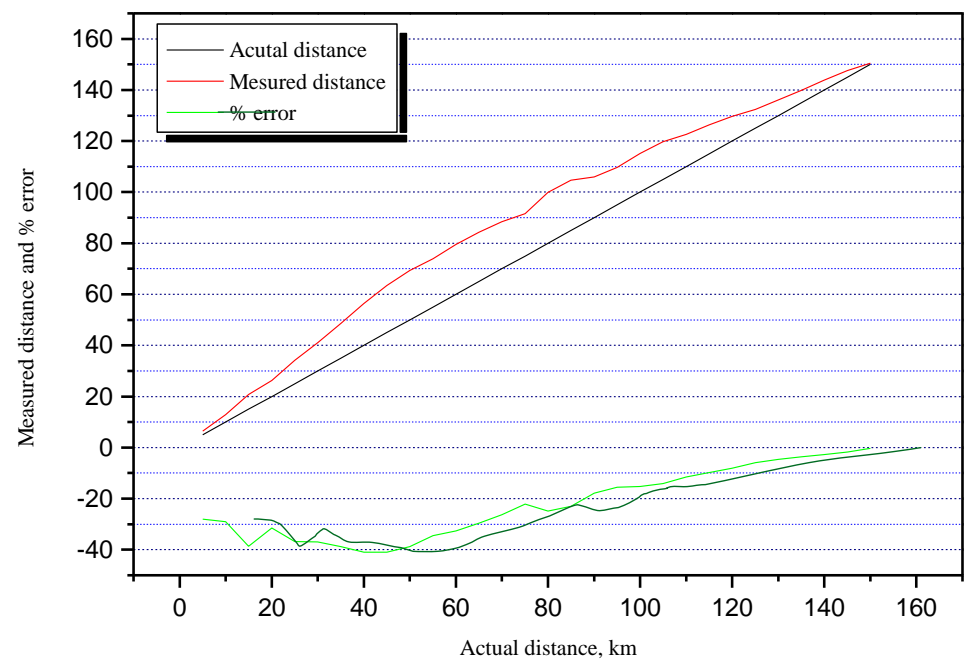

Fig. 7. The distance measured by the distance relays and the $\%$ error in this distance for L2-L3 fault, line 1 in service. 


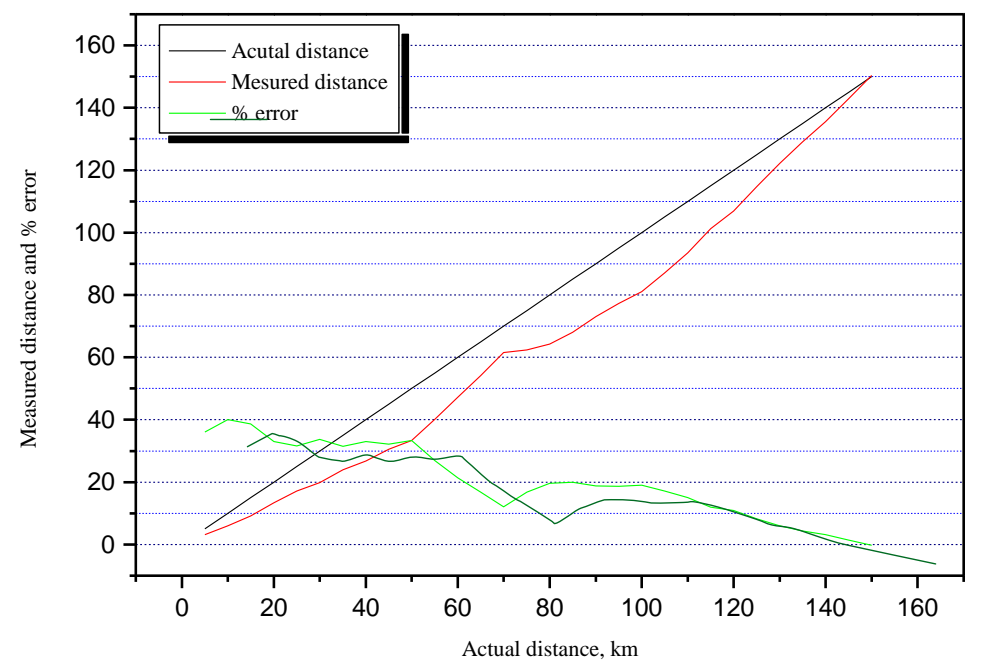

Fig. 8 . The distance measured by the distance relays and the $\%$ error in this distance for L1-L2-L3 fault, line 1 in service.

\section{FROM THESE FIGURES IT CAN BE NOTED THAT:}

1- $\quad$ Error exists between the distance measured by the distance relay units and the actual fault distance (according to fault location).

2- $\quad$ This error is small for the single line-to-ground faults (L1-G, L2-G and L3-G). It is large for the line-to-line faults (L1-L2, L1-L3 and L2-L3) and for the threephase fault (L1-L2-L3).

3- The error in the measured impedance is between $0.27 \%$ and $40 \%$ and affects the fault clearing time at some locations.

4- The error percentage does not depend on the fault position. At a particular fault position, the error percentage is not constant for different fault types. Also, for a particular fault type, the error percentage differs between fault loops.

5- This error has a clear effect on the operation of the distance relay units with faults near the limit of the first protection zone $(80 \%$ from the line length $=120$ $\mathrm{km})$. These faults may have actually occurred in the first zone, but appear in the second zone due to the relay error, or vice versa. For example, for the faults at a distance of $115 \mathrm{~km}$ (also at 110 and $120 \mathrm{~km}$ ) from Busbar A, the fault position is located in the first zone of relay R1. The relay cleared the L1-G, L2-G, L3-G, L1-L2, L1-L3 and L1-L2-L3 faults correctly in the first zone, but sees the L2-L3 fault in the second zone (the fault clearing time is greater). Fig. 9 shows the L2L3 fault results from the relay at this location. From this figure, it can be seen that the starting signals of the relay were generated in the first zone, whereas the trapping signal was generated in the second zone.

The fault clearing time for this fault is $360 \mathrm{msec}$. For the different fault types at a distance of $125 \mathrm{~km}$ from A, actually located in the second zone of relay R1, the relay cleared all the fault types correctly in the second zone, except the L1-L3 and L1-L2-L3 faults. The relay sees these two faults in the first zone. This is 
clear in Fig. 10, which shows the results of the distance relays for the L1-L2-L3 fault. This figure shows that the fault was cleared in the first zone with a fault clearing time of $110 \mathrm{msec}$.

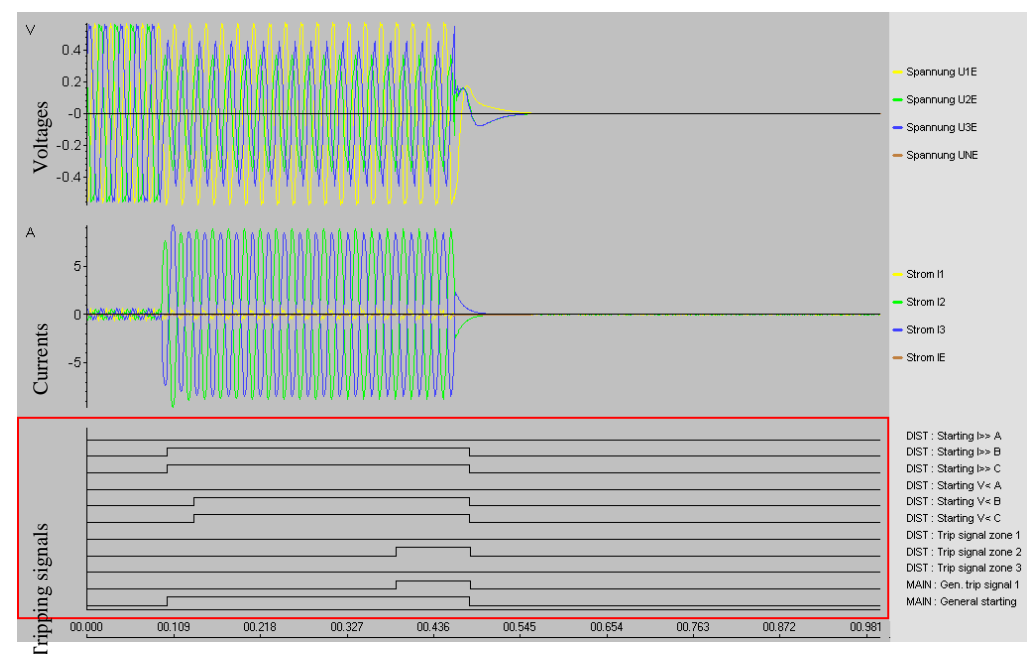

Fig. 9. The L2-L3 fault results at $115 \mathrm{~km}$ from station A.

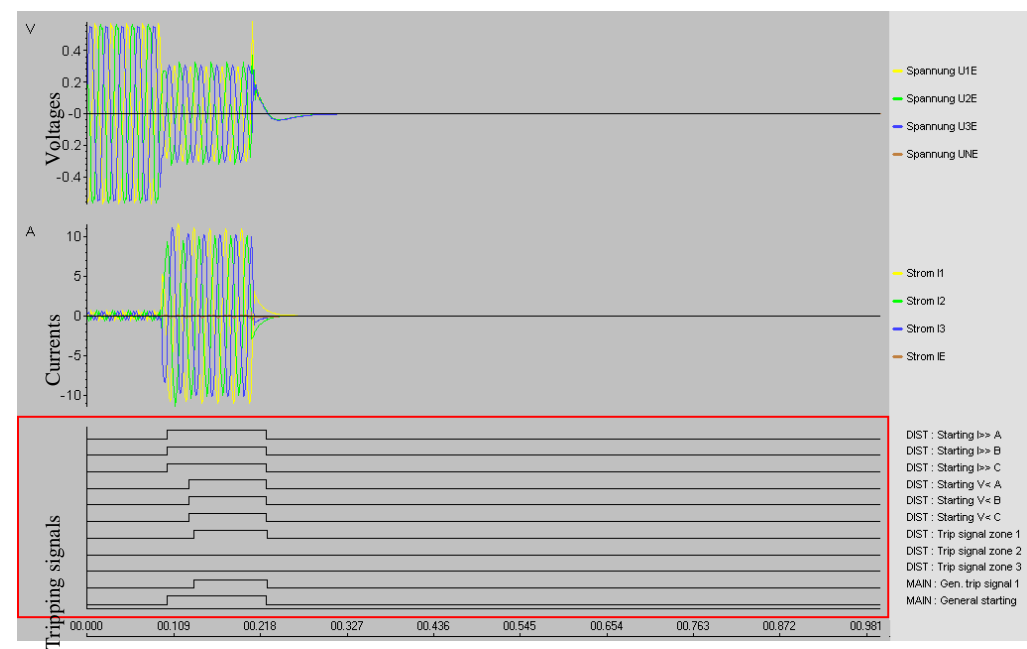

Fig. 10. The L1-L2-L3 fault results at $125 \mathrm{~km}$ from station A.

\section{THE NEW SETTING RULE PROPOSAL}

It is clear that the transposition operation of the phases successfully overcomes the unsymmetrical impedances at the end of the line. Also, the error percentage between the actual distance and the distance measured by the distance relay is very small near the end of the transmission line. At the same time, and under any setting rule, the entire transmission line will be completely isolated if any type of fault occurs at any location along it. 
Therefore, the proposed modification of the setting rule for the distance relay is to increase the setting of the relay's first protection zone. This zone can be taken to cover the entire line (100\% of the line length, instead of $80 \%$ as in the old setting rule) if the busbars are protected by the system protection. It will cover about $95 \%$ of the line if there is separate protection for the busbars.

The modification is done on the setting rule selected above (ref. [9]). The setting of the three main zones before and after the modification is shown in Table 1.

Table 1. The selected setting rule before and after modification.

\begin{tabular}{|l|l|l|}
\hline Zone & \multicolumn{1}{|c|}{ Original Setting rule } & \multicolumn{1}{c|}{ Modified setting rule } \\
\hline Zone 1 & $80 \%$ of the protected line & 95\% of the protected line \\
\hline Zone 2 & $\begin{array}{l}\text { protected line }+50 \% \text { of shortest } \\
\text { second line }\end{array}$ & $\begin{array}{l}\text { protected line }+50 \% \text { of shortest } \\
\text { second line }\end{array}$ \\
\hline Zone 3 & $\begin{array}{l}1.2 \text { (protected line + longest second } \\
\text { line). }\end{array}$ & $\begin{array}{l}1.2 \text { (protected line + longest second } \\
\text { line). }\end{array}$ \\
\hline
\end{tabular}

\section{EXPERIMENTAL WORK USING THE MODIFIED SETTING RULE}

The different types of shunt faults were made at different locations on the line, especially near the limit of the first protection zone (Zone 1 covers $142.5 \mathrm{~km}$ ). The faults were made inside the first and second protection zones. Figures 11 and 12 show a sample of the results from some of the cases that produced problems under the original setting rule. Figure 11 shows the L2-L3 fault results at $140 \mathrm{~km}$ from station A (in the first zone). The distance relay clears the fault correctly in the first zone. Fig. 12 shows the L1-L2-L3 fault results at $145 \mathrm{~km}$ from station A (in the second zone). The distance relay clears this fault correctly in the second zone.

From the experiments using the modified setting rule, it is clear that the relay operates correctly and clears the different types of shunt faults in the correct protection zones.

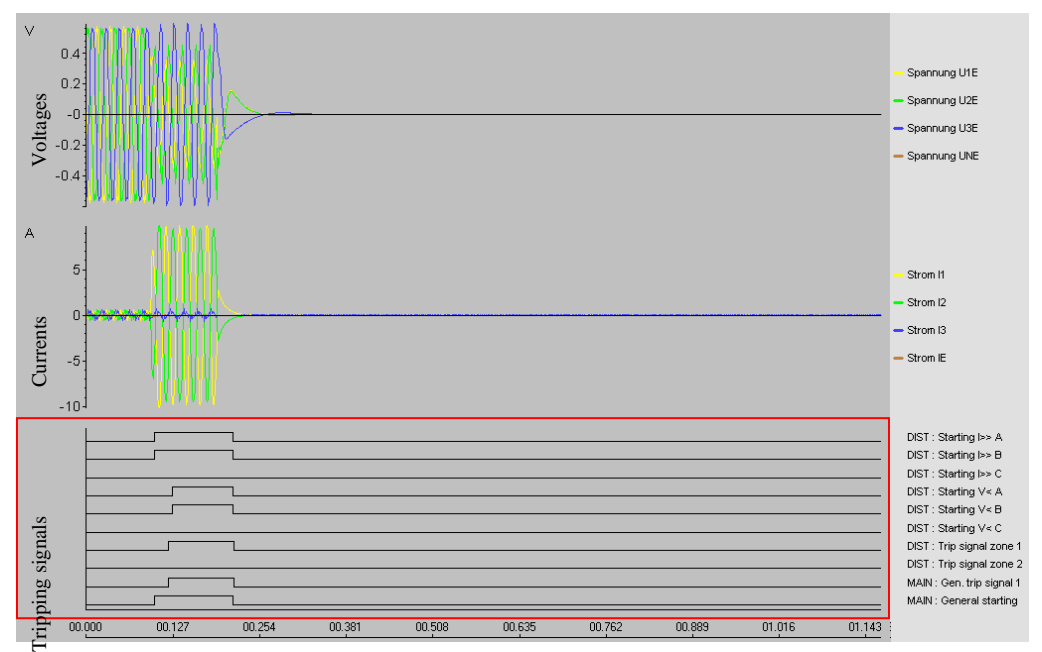

Fig. 11. The L2-L3 fault results at $140 \mathrm{~km}$ from station A. 


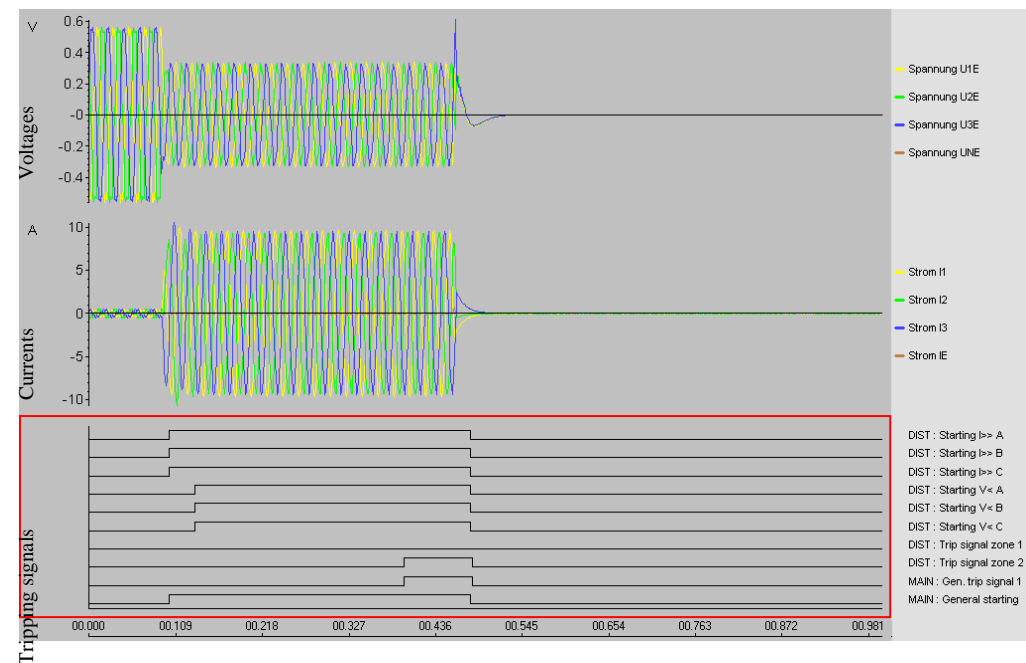

Fig. 12. The L1-L2-L3 fault results at $145 \mathrm{~km}$ from station A.

\section{CONCLUSION}

The new setting rule (after modification) overcomes the problem of unsymmetrical impedances in the transposed transmission line. Different types of fault are cleared correctly in the appropriate protection zone.

\section{REFERENCES}

[1] Yi Hu, Damir Novosel, Murari Mohan Saha and Voker leitloff, "An adaptive scheme for parallel-line distance protection", IEEE Transactions on Power Delivery, Vol. 17, No. 1, pp. 105-110, 2002.

[2] Ming Jin and Tarlochan S. Sidhu, "Adaptive load encroachment prevention scheme for distance protection", Electric Power Systems Research, Volume 78, Issue 10, pp. 1693-1700, October 2008

[3] J. Izykowski, E. Rosolowski and M. Saha, "Postfault analysis of operation of distance protective relays of power transmission lines", IEEE Transactions on Power Delivery, Vol. 22, No. 1, pp. 74-81, 2007.

[4] N. Perera and A.D. Rajapakse, "Fast isolation of faults in transmission systems using current transients", Electric Power Systems Research, Volume 78, Issue 9, pp. 1568-1578, September 2008.

[5] Marija Bockarjova, Antans Sauhats and Goran Andersson, "Statistical algorithm for power transmission lines distance protection", $9^{\text {th }}$ International Conference on Probablilistic Methods Applied to Power Systems, KTH, Stockholm, Sweeden, pp. 1-7, June 11-15, 2006.

[6] Juan M. Gers and Edward J. Holmes, 'Protection of Electricity Distribution Networks', Book, 1988.

[7] Stanley H. Horowitz and Arun G. Phadke, 'Power System Relaying', Book, Second edition, 1995.

[8] Gerhard Zigeler, 'Numerical protection principles and application", Book, Erlangen Publicis-MCD-Verl., 1999. 
[9] GEC Measurements, 'Protective Relays Application Guide', General Electric Company p.l.c. of England, 1975.

[10] K. W. Leung, "Computer-aided setting calculation for distance zone 2 and zone 3 protection", IEE International Conference on Advances in Power System Control, Operation and Management, Hong Kong, November 1991.

[11] Abou-Hashema M. El-Sayed. "Application of computers in the digital protection of renewable and conventional electrical power system", Ph. D. Thesis, Electrical Engineering Dept., Faculty of Engineering, Minia University, Egypt, 2002.

[12] H.H.EL-Tamaly, Abou-Hashema M. El-Sayed, "A New Technique for Setting Calculation of Digital Distance Relays", The Eleventh International Middle East Power Systems Conference (MEPCON'2006), PES, IEEE, Department of Electrical Engineering, Faculty of Engineering, El-minia University, El-minia, Egypt, PP 135-139, December 19 - 21, 2006.

\section{بروتوكول جديد لتضبيط نظام وقاية مسافى لخط نقل متبادل الاوجه ذو معاوقات غير متساوية}

يهذف هذا البحث الى التغلب على التأثير السلبى لخطوط نقل القدرة الكهربية ذات المعاوقات الغير منساوية والتى تتغير فية اماكن الاوجة بالنسبة الى بعضها البعض على نظم الوقاية. من المعروف

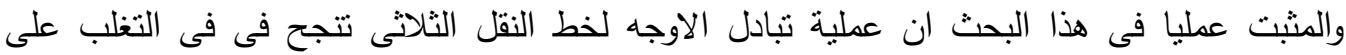
مشكلة عدم تساوى المعاوقات عند نهاية الخط فقط ولكنها تفشل فى التغلب على هذة المشكلة فى باقى لإدى اجزاء خط النقل. تأثنر هذة المشكلة يظهر جليا فى المسافة المقاسة بواسطة وحدة الوقاية المسافية.

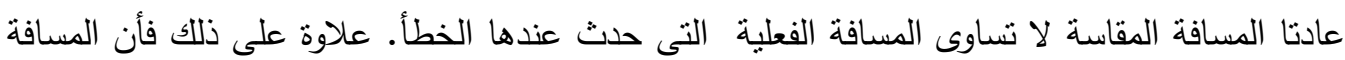

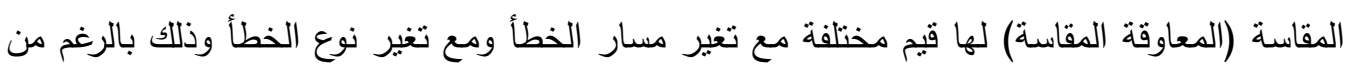

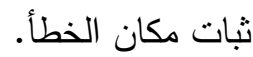

تم عمل تجارب معملية لدراسة نأثير عدم تساوى المعاوقة لهذا النوع من خطوط النقل على عمل نظام

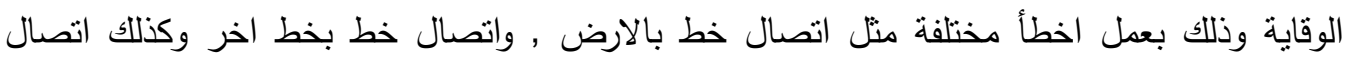

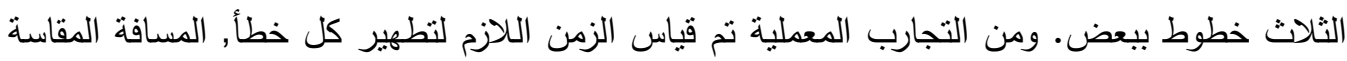
بواسطة وحدة الوقاية المسافية وكذلك نسبة الخطأ فى المسافة المقاسة.

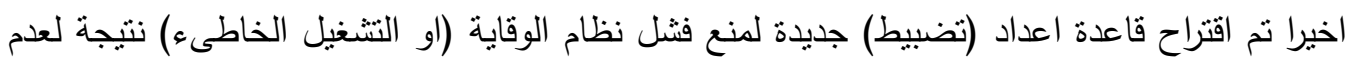
نساوى المعاوقات لهذا النوم من خطوط النقل واثثت هذا المقترح نجاحة عمليا. 